\title{
Souvenir Batik Motif Bangunan Kampung Heritage dengan Teknik SMOK Sebagai Modal Kemampuan Berwirausaha Masyarakat Kayutangan Malang
}

\author{
${ }^{1 *}$ Lisa Sidyawati, ${ }^{2}$ Ponimin, ${ }^{3}$ Swastika Dhesti Anggriani \\ Universitas Negeri Malang; Jalan Semarang 5 Malang \\ *Corresponding author: lisasidyawati@gmail.com
}

\begin{abstract}
Abstrak
Sejarah kota Malang tidak bisa lepas dari keberadaan Kayutangan. Pada era kolonial Belanda, kawasan ini menjadi pusat bisnis, yang hingga sekarang masih bertahan, bahkan telah ditetapkan sebagai bangunan Heritage ke perwakilan pengelola 32 bangunan di Kota Malang 10 diantaranya berada dalam kawasan Kayutangan. Diantara bangunan-bangunan heritage terdapat gang yang juga dipenuhi rumah-rumah heritage, disanalah terdapat Kampung Heritage Kayutangan. Kampung Heritage Kayutangan sekarang ini menjadi salah satu destinasi wisata, dimana warganya sangat membuka diri dan menyiapkan rumah mereka sebagai titik swafoto. Namun ketika berkunjung ke Kampung Heritage Kayutangam, baik wisatawan lokal maupun wisatawan asing kesulitan mencari souvenir yang khas. Pengebdian ini bertujuan mengajak warga untuk dapat menumbuh kembangkan kemampuan berwirausaha yang selanjutnya mampu mengangkat potensi daerah melalui Pelatihan Pembuatan Souvenir Batik Motif Bangunan Kampung Heritage Kayutangan Malang dengan Teknik Smok. metode yang digunakan adalah Participatory Rural Appraisal. Hasil kegiatan ini terdapat pengembangan Kemampuan Berwirausaha Masyarakat dengan produk unggulan membuat Souvenir Wisatawan terutama bagi wisatawan asing berupa t-shirt dan goodie bag.
\end{abstract}

Kata kunci-Heritage Malang, Kayu Tangan, Teknik SMOK

\begin{abstract}
The history of Malang cannot be separated from the existence of Kayutangan. In the Dutch colonial era, this area became a business center, which until now still survives, even has been designated as a Heritage building to the representative of the management of 32 buildings in Malang. 10 of them are in the Kayutangan area. Among the heritage buildings there are alleys which are also filled with heritage houses, there is Heritage Kayutangan Village. Kayutangan Heritage Village is now one of the tourist destinations, where the residents are very open and preparing their homes as a selfie point. But when visiting the Kayutangam Heritage Village, both local and foreign tourists have difficulty finding distinctive souvenirs. This service aims to invite citizens to be able to develop and develop entrepreneurial skills which are then able to raise the potential of the region through the Training of Making Batik Motifs in Malang Kayutangan Heritage Village Building with Smok Technique. The method used is Participatory Rural Appraisal. The result of this activity is the development of Community Entrepreneurial Ability with superior products making Tourist Souvenirs especially for foreign tourists in the form of $t$-shirts and goodie bags.
\end{abstract}

Keywords-Heritage Malang, Hand Wood, SMOK Engineering.

\section{PENDAHULUAN}

$\mathrm{M}$ enurut data laman resmi Badan Pusat Statistik (BPS) Kota Malang menunjukkan angka kunjungan wisatawan asing yang datang ke Kota Malang terhitung akhir tahun 2018 melonjak hingga lebih dari $100 \%$ di bandingkan tahun 2017. Tercatat terdapat 15 ribu turis asing yang berekreasi di kota pendidikan ini. Angka tersebut naik dibandingkan tahun sebelumnya dimana jumlah wisatawan asing yang berkunjung hanya enam ribuan orang. Angka tersebut juga melebihi target yang telah ditetapkan 


\section{Sidyawati dkk. / Jurnal Karinov Vol. 2 No. 3 (2019) 161-166}

Pemerintah Kota Malang. Tingginya kunjungan wisatawan asing, membuat Malang menjadi salah satu kota yang menempati rangking tertinggi kunjungan dibandingkan Yogyakarta, Bali dan Bandung.

Kepala Dinas Pariwisata Kota Malang dalam media massa online Malang Times menjelaskan, bahwa wisatawan asing berkunjung karena tertarik dengan kenangan dan bangunan heritage yang dimiliki Kota Malang. Melihat fenomena seperti itu sudah seharusnya kekuatan wisata heritage di Kota Malang terus dipromosikan oleh seluruh lapisan masyarakat. Selain itu, pemerintah juga memiliki program kerja promosi jangka panjang diantaranya rencana dikembalikannya kawasan Kayutangan sebagaimana wajah aslinya. Sejarah kota Malang tidak bisa lepas dari keberadaan Kayutangan. Pada era kolonial Belanda, kawasan ini menjadi pusat bisnis, yang hingga sekarang masih bertahan. Banyak bangunan-bangunan peninggalan Belanda yang tetap dipertahankan bentuk aslinya. Meskipun tidak sedikit pula yang sudah berubah, baik fungsi maupun arsitektur bangunannya. Kawasan Kayutangan atau di zaman Belanda dikenal dengan nama Jalan Pita adalah sebuah daerah terbentang mulai dari pertigaan PLN sampai ke Gereja Kayutangan. Disebut dengan Kayutangan karena di ujung jalan arah alun-alun terdapat pohon yang menyerupai tangan. Kayutangan (Kajoetangan) banyak terdapat di buku laporan Belanda tahun 1890 hingga masih diucapkan sampai sekarang. Tanggal 14 Januari 2019 Walikota Malang menyerahkan sertifikat penetapan bangunan Heritage ke perwakilan pengelola 32 bangunan di Kota Malang. Dari 32 bagunan heritage yang ada di Malang 10 diantaranya berada dalam kawasan Kayutangan, bangunan heritage di wilayah Kayutangan itu adalah: (1). Perempatan Kayutangan, atau disebut perempatan Radjabally, (2). Kantor Telkom, (3). Monumen Chairil Anwar, (4). Toko Oen, (5). Gereja Hati Kudus Yesus atau Gereja Kayutangan, (6). Pertokoan Sarinah, (7). Gereja Emmanuel, (8). Masjid Jami' Agung, (9). Hotel Pelangi, (10). Balai Kota Malang.

Kayutangan memiliki potensi begitu besar serta strategis dengan terdapatnya bangunan heritage. Diantara bangunan-bangunan heritage terdapat gang yang juga dipenuhi rumah-rumah heritage, disanalah terdapat Kampung Heritage Kayutangan yang telah diresmikan oleh pemerintah]. Ada 60 rumah tua yang berhasil diidentifikasi masih utuh. Seluruhnya relatif terjaga bentuk aslinya. Di depan rumah dipasang plakat informasi usia bangunan sampai pemilik pertamanya. Rumah tertua dicatat dibangun pada
1870. Banyak pula yang dibangun dalam kurun 19201940 dengan model atap pelana atau biasa disebut rumah jengki. Selain itu, ditampilkan pula barangbarang dari masa lalu seperti radio, televisi, alat makan jadul hingga makanan serta camilan tradisional.

Kampung Heritage Kayutangan sekarang ini menjadi salah satu destinasi wisata, dimana warganya sangat membuka diri dan menyiapkan rumah mereka sebagai titik swafoto. Dari seluruh rumah bergaya arsitektur Belanda, ada 25 rumah siap menerima wisatawan. Menyediakan berbagai properti untuk berfoto sembari pemiliknya tetap beraktivitas seperti biasa. Kampung ini bukan cuma wisata namun memang kampung yang dihuni oleh penduduk. Jadi selayaknya permukiman padat, ada banyak aktivitas warga di sana.

Namun ketika berkunjung ke Kampung Heritage Kayutangam, baik wisatawan lokal maupun wisatawan asing kesulitan mencari souvenir yang khas dan tahan lama untuk bisa dibawa kembali ke negaranya. Selama ini, souvenir yang terkenal dan merebak di Kota Malang adalah kuliner kripik buah dan kue-kue artis di berbagai sudut. Masyarakat Kayutangan belum sadar akan potensi khas yang dimiliki dapat diolah untuk menghasilkan usaha dan uang, kekhasan tersebut tidak dimiliki oleh wilayah lain di Malang. Kampung Heritage Kayutangan dapat dioptimalkan menjadi wilayah yang mampu bersaing dalam era industri kreatif.

Oleh karena itu pengabdi mengajak para warga untuk dapat menumbuh kembangkan kemampuan berwirausaha yang selanjutnya mampu mengangkat potensi daerah. Selain dapat menghasilkan uang, juga sebagai sarana promosi Kampung Haritage Kayutangan. Untuk mendukung usaha tersebut pengabdi akan melakukan "Pelatihan Pembuatan Souvenir Batik Motif Bangunan Kampung Heritage Kayutangan Malang dengan Teknik Smok Sebagai Modal Kemampuan Berwirausaha Masyarakat untuk Melayani Souvenir Wisatawan Asing". Souvenir bukan hanya menyimpan memori akan perjalanan yang dilakukan melainkan juga sebagai ikon dari daerah tujuan wisata sekaligus memberi andil dalam mendukung pariwisata. Sehingga usaha souvenir ini dalam jangka panjang akan menjdikan lapangan kerja baru dan menjadi media promosi budaya Indonesia khususnya Malang di kancah internasional.

\section{METODE}

Tahapan Pelatihan Pembuatan Souvenir Batik Motif Bangunan Kampung Heritage Kayutangan 
Malang dengan Teknik Smok Sebagai Modal Kemampuan Berwirausaha Masyarakat untuk Melayani Souvenir Wisatawan Asing dapat dijabarkan sebagai berikut

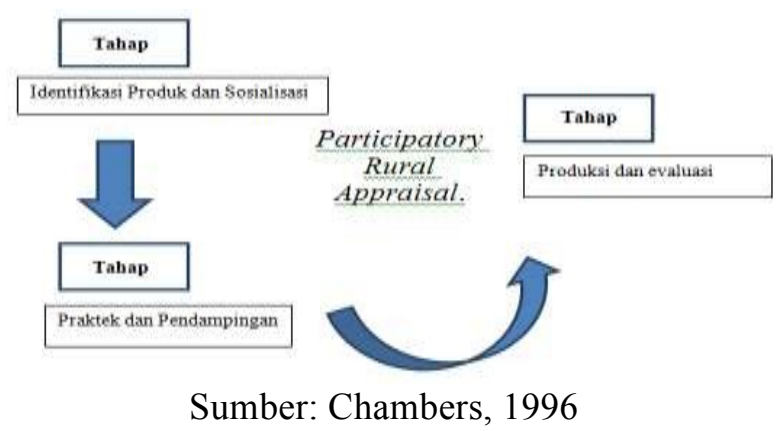

Gambar 1. Prosedur Participatory Rural Appraisal

Prosedur pengabdian kepada masyarakat ini menggunakan pendekatan Participatory Rural Appraisal (PRA) atau Pemahaman Partisipatif Kondisi Pedesaan (PRA) adalah pendekatan dan metode yang memungkinkan masyarakat secara bersama-sama menganalisis masalah kehidupan dalam rangka merumuskan perencanaan dan kebijakan secara nyata. Pada intinya PRA adalah sekelompok pendekatan atau metode yang memungkinkan masyarakat untuk saling berbagi, meningkatkan, dan menganalisis pengetahuan mereka tentang kondisi dan kehidupan nya serta membuat rencana dan tindakan nyata (Chambers,1996). Langkah Participatory Rural Appraisal dapat dijabarkan sebagai berikut.

\section{a. Tahap Persiapan (Identifikasi Produk dan Sosialisasi)}

1. Pada tahapan ini pengabdi melakukan observasi ke Kampung Heritage Kayutangan mendapatkan data mengenai bangunan yang dapat dijadikan sebagai inspirasi motif untuk produk souvenir yang di butuhkan dan dapat dikembangkan di wilayah ini. Pengabdi juga melakukan diskusi dengan warga Kayutangan untuk mengetahui potensi kesediaan masyarakat mengembangkan wilayahnya yang ditindak lanjuti dengan pelatihan pembuatan souvenir khas Kampung Heritage Kayutangan

2. Mensosialisasikan gambaran rencana produk kepada masyarakat Kampung Heritage Kayutangan dan melakukan kesepakatan produk souvenir yang diciptakan dan didapatkan produk berupa t-shirt dan goodie bag, selanjutnya pengabdi menindaklanjuti pengurusan surat tugas dari kampus sekaligus surat izin resmi kepada Pengurus Kampung Heritage
Kayutangan.

b. Tahap Pelaksanaan (Praktek dan Pendampingan)

Tahapan praktek dan pendampingan ini merupakan tahapan proses pembuatan produk souvenir t-shirt dan goodie bag batik motif bangunan Kampung Heritage Kayutangan Malang dengan teknik smok, dan tim pengabdi mendampingi pada setiap langkah pembuatan serta memberikan masukan dan konsultatif jika ada peserta yang belum berhasil menguasai ketrampilan pada setiap langkahnya.

\section{c. Tahap Monitoring dan Evaluasi}

1. Pada tahapan ini pengabdi melakukan observasi ke Kampung Heritage Kayutangan mendapatkan data mengenai bangunan yang dapat dijadikan sebagai inspirasi motif untuk produk souvenir yang di butuhkan dan dapat dikembangkan di wilayah ini. Pengabdi juga melakukan diskusi dengan warga Kayutangan untuk mengetahui potensi kesediaan masyarakat mengembangkan wilayahnya yang ditindak lanjuti dengan pelatihan pembuatan souvenir khas Kampung Heritage Kayutangan

2. Tahap Evaluasi pada pelatihan ini yaitu kegiatan meninjau kembali kesulitan-kesulitan dan potensi-potensi dalam proses pembuatan produk sehingga ditemukan solusi-solusi yang bisa meningkatkan produksi produk

\section{HASIL DAN PEMBAHASAN}

\section{a. Konsep Batik Motif Bangunan Kampung Heritage Kayutangan}

Masyarakat Kampung Heritage Kayutangan dilatih untuk membuat produk souvenir batik bangunan Heritage Kampung Kayutangan dengan teknik smok dan diwujudkan pada produk t-shirt dan goodie bag terdiri, tampilan produk tersebut dirancang dengan memenuhi enam unsur visual yaitu: (1). Unsur bentuk yang terlihat bahwa motif batik ini berbentuk ragam bangunan Kampung Heritage Kayutangan sebagai identitas ikon wilayah, (2). Unsur warna diperoleh dari teknik smok yang akan menimbulkan efek warna, (3). Unsur skala ukuran yaitu ukuran diaplikasikanya motif sesuai dengan kebutuhan produk, (4). Unsur garis didapatkan dari isen-isen dan klowongan yang diulang-ulang pada motif ketika menggambarkan bangunan heritage, (5). Unsur tekstur ada pada 
perbedaan dan tebal tipisnya yang ditimbulkan pada smok, (6). Unsur kecerahan juga di dapatkan dari efek pewarnaan dimana produk satu dengan produk yang lain dengan teknik pewarnaan yang sama yaitu dengan menggunakan smok didapatkan intensitas kecerahan yang berbeda. Hal tersebut didesain sesuai dengan hakekat unsur-unsur visual desain Marvin Bartel (1999) dalam bukunya Elements and Principle of Design, menyatakan "Unsur visual desain terdiri dari yaitu unsur garis, warna, bentuk, skala ukuran, tekstur, tingkat kecerahan. Sehingga dengan adanya 6 unsur visual tersebut dapat memunculkan sketsa desain produk fashion yang unik menarik".

Desain motif batik yang diciptakan oleh masyarakat Kampung Heritage Kayutangan tersebut inspirasinya diambil dari bangunan yang ada disana. Pilihan bangunan dan desain motif batik dipilih atas diskusi bersama diantara masyarakat dan salah satu anggota masyarakat yang bernama Mila mewujudkan gagasan yang telah disepakati menjadi desain motif atas bimbingan pengabdi, setelah itu desain motif diaplikasikan pada bagian depan t-shirt dan goodie bag. Untuk konsep pembuatan desain motif batik dapat dijabarkan sebagai berikut.

1. Inspirasi dari Rumah 1870
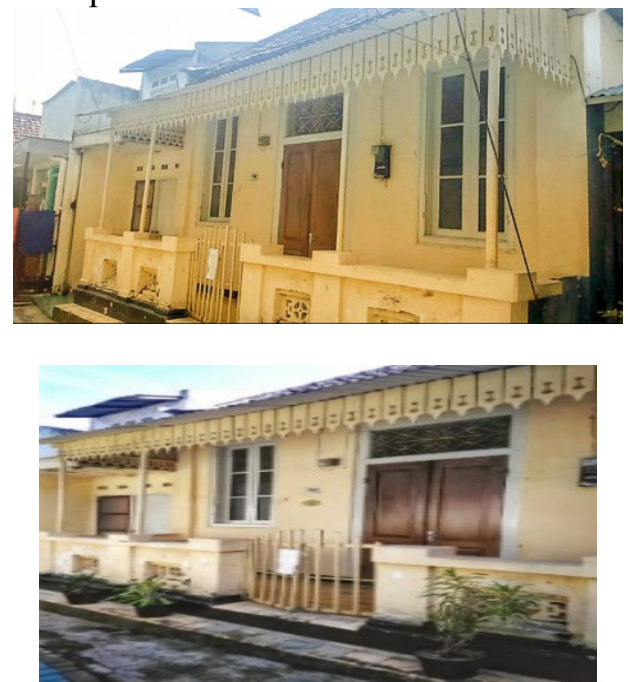

Sumber: Dokumentasi Pengabdi, 2019

Gambar 2. Rumah 1870

Rumah 1870 adalah rumah yang dibangun oleh generasi pertama salah satu keluarga bernama Nur Wasil dengan ukuran $8 \times 11$ meter dengan atas berbentuk perisai, dengan interior yang terdiri dari ruang bawah dan loteng. Salah satu yang menjadi titik perhatian menarik di rumah ini adalah elemen di depan rumah yang bergaya klasik.

Dari inspirasi rumah tahun 1870 tersebut dapat dijadikan desain motif batik melalui proses stilasi. Menurut Triyanto (2012:46) Teknik mengembangkan objek atau desain ada 4 macam, yaitu: teknik stilasi, teknik distorsi, teknik transformasi, dan teknik disformasi. Untuk mendesain motif batik Bangunan Kampung Heritage kayutangan ini dipilih teknik stilasi karena pengabdi ingin mendapatkan bentukbentuk baru yang lebih indah dan lebih menarik untuk dijadikan souvenir, desain motif batik dapat divisualisasikan sebagai berikut.

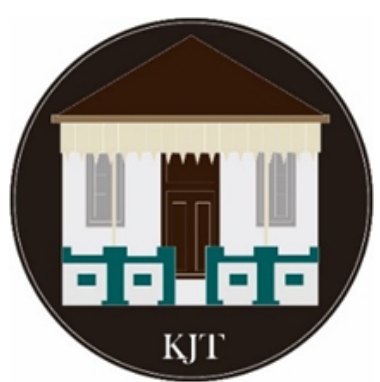

Sumber: Dokumentasi Pengabdi, 2019

Gambar 3. Desain Motif Batik Rumah 1870

2. Inspirasi dari Rumah Penghulu

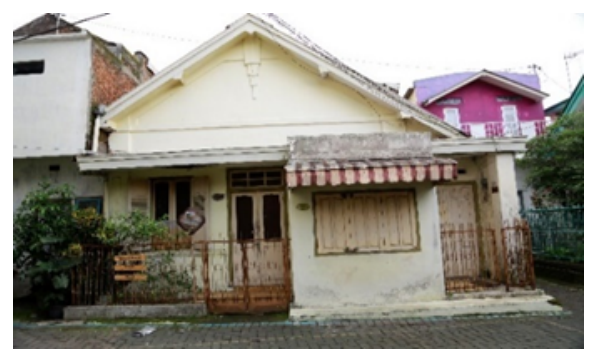

Sumber: Dokumentasi Pengabdi, 2019

Gambar 4. Rumah Penghulu

Rumah penghulu adalah rumah seorang penghulu pernikahan jaman kolonial, beliau dulu sering menjadi penghulu pernikahan masyarakat sekitar Kampung Heritage Kayutangan. Rumah ini memiliki arsitektur klasik dan berwarna nuansa coklat kekunging-kuningan, khas nuansa klasik, serta memiliki atap pelana, terdapat jendela besar tepat di depan rumah. Dari inspirasi rumah penghulu tersebut dapat dijadikan desain motif batik yaang dapat divisualisasikan sebagai berikut.

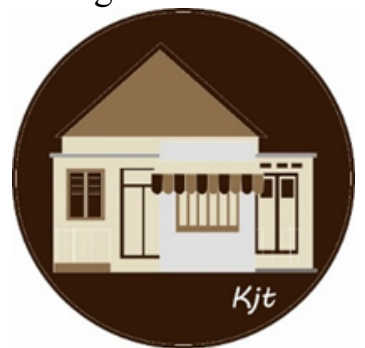

Sumber: Dokumentasi Pengabdi, 2019

Gambar 5. Desain Motif Batik Rumah Penghulu 
3. Inspirasi dari Rumah Namsin
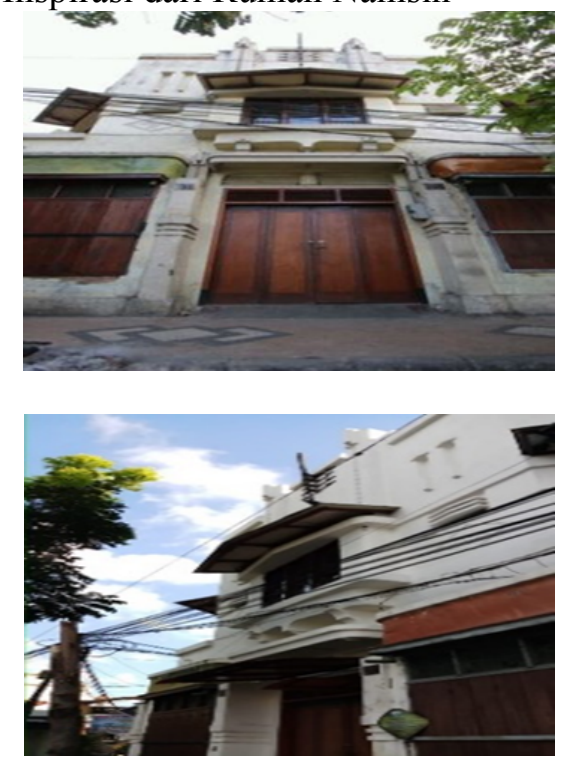

Sumber: Dokumentasi Pengabdi, 2019

Gambar 6. Rumah Namsin

Bangunan ber-arsitektur Belanda ini memiliki daun pintu yang tinggi dan khas berwarna cokelat diperkirakan berdiri pada tahun 1900-an. Awalnya bangunan ini digunakan untuk bengkel mobil. Namun pada tahun 1950-an rumah ini dibeli oleh keluarga Namsin dan digunakan untuk membuat es lilin. Meski begitu, keluarga Namsin tidak merubah sejarah bangunan ini sama sekali. Di dalam bangunan itu masih utuh onderdil dan kwitansi bengkel mobil.

Dari inspirasi rumah Namsin tersebut dapat dijadikan desain motif batik yaang dapat divisualisasikan sebagai berikut.

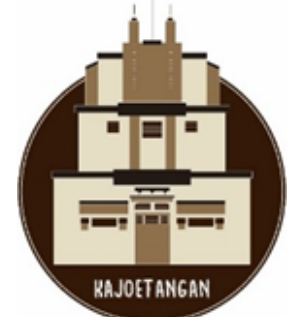

Sumber: Dokumentasi Pengabdi, 2019

Gambar 7. Desain Motif Batik Rumah Namsin

\section{b. Proses Penciptaan Batik Motif Bangunan \\ Kampung Heritage Kayutangan Malang \\ Dengan Teknik SMOK}

Dari hasil desain motif batik diatas, masyarakat Kampung Heritage Kayutangan dilatih untuk mengaplikasikan pada t-shirt dan goodie bag dengan cara menggambar atau menjiplak motif tersebut diatas kaian selanjutnya dicanting seperti pembuatan batik pada umumnya. Menurut pendapat sebagian besar masyarakat, proses pencantingan adalah proses yang paling sulit dilakukan, proses ini membutuhkan kesabaran dan ketelatenan, selain itu ada beberapa masyarakat yang hanya memiliki sedikit waktu karena harus berjualan maupun melakukan kegiatan lainnya sehingga proses pencantingan membutuhkan waktu lebih dari sehari, namun warga yang tidak bisa menyelesaikan pada hari itu berinisiatif mencanting dirumah masing-masing pada waktu malam hari disaat tidak berkegiatan.

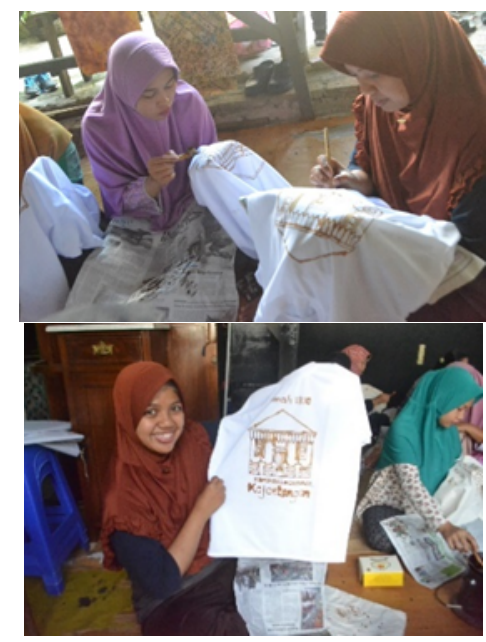

Sumber: Dokumentasi Pengabdi, 2019

Gambar 8. Proses Pencantingan Motif Batik

Bangunan Kampung Heritage Kayutangan

Proses selanjutnya adalah pewarnaan dengan menggunakan teknik smok, motif yang sudah dicanting pada t-Shirt dan goodie bag oleh masyarakat Kampung Heritage Kayutangan pengabdi bimbing untuk diwarna dengan menggunakan teknik smok yang dapat dideskripsikan langkah-langkahnya sebagai berikut.
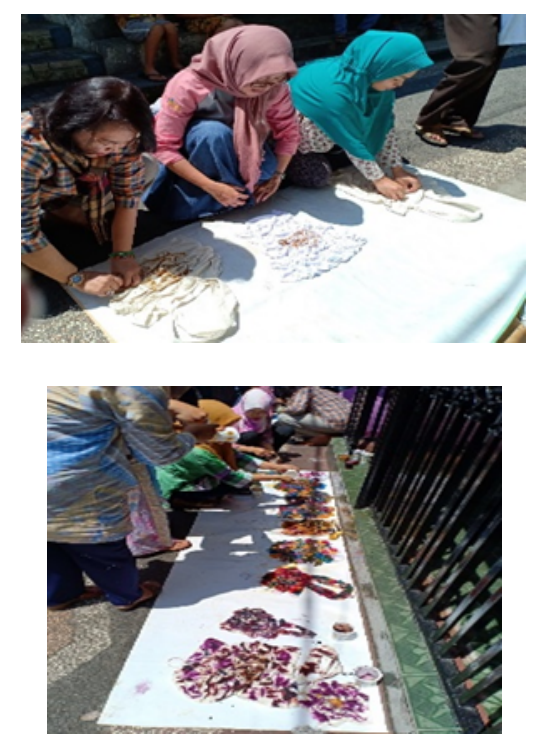

Sumber: Dokumentasi Pengabdi, 2019

Gambar 9. Proses Pewarnaan dengan Teknik SMOK

Page | 165 
Sidyawati dkk. / Jurnal Karinov Vol. 2 No. 3 (2019) 161-166

T-shirt dan goodie bag yang telah dicanting motifnya, diletakkan di bawah sinar matahari langsung dan di cubit-cubit sesuai dengan kebutuhan, cubitan ini nantinya akan memberikan efek warna seperti asap yang menyebar. Setelah dicubit, diwarna dengan menggunakan pewarna batik berjenis remasol dengan alat spons dengan cara ditutulkan sesuai dengan warna yang diinginkan, setelah kering dibuka dan celupkan pengunci warna dengan menggunakan waterglass. Hasil Akhir Produk ini dapat ditampilkan sebagai berikut.
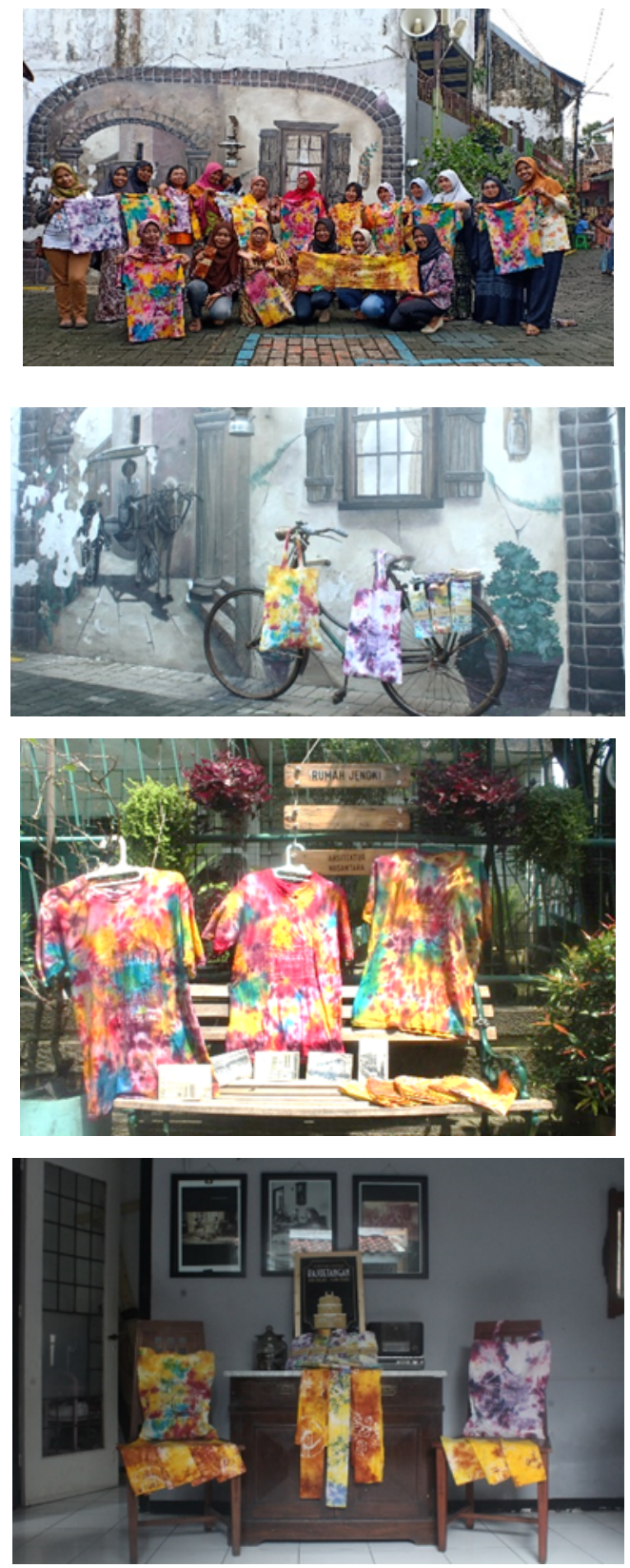

Sumber: Dokumentasi Pengabdi, 2019

Gambar 10. Produk Souvenir T-shirt dan Goodie Bag Batik Motif Bangunan Heritage Kayutangan dengan Teknik SMOK

\section{SIMPULAN}

Pelatihan pembuatan souvenir batik motif bangunan Kampung Heritage dengan teknik smok sebagai modal kemampuan berwirausaha masyarakat Kayutangan Malang ini sangat bermanfaat dan berjalan dengan baik dibuktikan dengan antusiasme warna menghasilkan produk sampai akhir. Pengabdi telah berhasil memberikan wawasan akan pentingnya souvenir dalam suatu sistem pengeloaan wisata serta penggalian potensi-potensi lokal yang mampu menjadi ikon serta daya tarik wisatawan. Pengabdi juga telah berhasil melatih ketrampilan masyarakat Kampung Heritage Kayutangan dalam bidang batik mulai dari proses penggalian ide, pembuatan motif, pecantingan dan pewarnaan yang mampu diaplikasikan setelah penagdian selesai oleh warga sendiri.

\section{DAFTAR RUJUKAN}

Bartel, M., (1999). Elements and Principole of Design, Goshen: College Press.

Chamber, R. (1996). Participatory Rural Appraisal: Memahami Desa secara Partisipatif. OxamKanisius:Yogyakarta

Triyanto. (2012). Mendesain Aksesori Busana. Sleman : PT Intan Sejati Klaten

https://malangkota.bps.go.id/. Diakses pada tanggal 7 Maret 2019

https://www.malangtimes.com/baca/43419/20190830 /194900/minus-sanusi-kayutangan-diresmikanjadi-ibukota-heritage-malang-raya. Diakses pada tanggal 7 Maret 2019 